\title{
Synthesis, Characterization, Cytotoxic Activity, and Interactions with CT-DNA and BSA of Cationic Ruthenium(II) Complexes Containing Dppm and Quinoline Carboxylates
}

\author{
Edinaldo N. da Silva, ${ }^{1}$ Paulo A. B. da Silva, ${ }^{1}$ Angélica E. Graminha, ${ }^{2}$ \\ Pollyanna F. de Oliveira, ${ }^{3}$ Jaqueline L. Damasceno, ${ }^{3}$ Denise C. Tavares, ${ }^{3}$ \\ Alzir A. Batista, ${ }^{2}$ and Gustavo Von Poelhsitz ${ }^{1}$ \\ ${ }^{1}$ Instituto de Química, Universidade Federal de Uberlândia, 38400-902 Uberlândia, MG, Brazil \\ ${ }^{2}$ Departamento de Química, Universidade Federal de São Carlos, 13565-905 São Carlos, SP, Brazil \\ ${ }^{3}$ Universidade de Franca, 14404-600 Franca, SP, Brazil
}

Correspondence should be addressed to Gustavo Von Poelhsitz; gustavopoelhsitz@ufu.br

Received 6 March 2017; Revised 30 May 2017; Accepted 13 June 2017; Published 26 July 2017

Academic Editor: Claudio Pettinari

Copyright (C) 2017 Edinaldo N. da Silva et al. This is an open access article distributed under the Creative Commons Attribution License, which permits unrestricted use, distribution, and reproduction in any medium, provided the original work is properly cited.

\begin{abstract}
The complexes cis- $\left[\mathrm{Ru}(\right.$ quin $\left.)(\mathrm{dppm})_{2}\right] \mathrm{PF}_{6}$ and cis- $\left[\mathrm{Ru}(\mathrm{kynu})(\mathrm{dppm})_{2}\right] \mathrm{PF}_{6}$ (quin = quinaldate; kynu = kynurenate; dppm = bis(diphenylphosphino)methane) were prepared and characterized by elemental analysis, electronic, FTIR, ${ }^{1} \mathrm{H}$, and ${ }^{31} \mathrm{P}\left\{{ }^{1} \mathrm{H}\right\} \mathrm{NMR}$ spectroscopies. Characterization data were consistent with a cis arrangement for the dppm ligands and a bidentate coordination through carboxylate oxygens of the quin and kynu anions. These complexes were not able to intercalate CT-DNA as shown by circular dichroism spectroscopy. On the other hand, bovine serum albumin (BSA) binding constants and thermodynamic parameters suggest spontaneous interactions with this protein by hydrogen bonds and van der Waals forces. Cytotoxicity assays were carried out on a panel of human cancer cell lines including HepG2, MCF-7, and MO59J and one normal cell line GM07492A. In general, the new ruthenium(II) complexes displayed a moderate to high cytotoxicity in all the assayed cell lines with $\mathrm{IC}_{50}$ ranging from 10.1 to $36 \mu \mathrm{M}$ and were more cytotoxic than the precursor cis- $\left[\mathrm{RuCl}_{2}(\mathrm{dppm})_{2}\right]$. The cis- $\left[\mathrm{Ru}(\mathrm{quin})(\mathrm{dppm})_{2}\right] \mathrm{PF}_{6}$ were two to three times more active than the reference metallodrug cisplatin in the MCF-7 and MO59J cell lines.
\end{abstract}

\section{Introduction}

The disseminated use of cisplatin and other platinum based metallodrugs as chemotherapeutic agents against ovarian, bladder, and testicular cancers, among others, is still a key aspect for the development of the medicinal inorganic chemistry [1-4]. In the search for coordination compounds active against tumors and less toxic than cisplatin, ruthenium compounds emerge as the most promising with biological features including mechanism of action, toxicity, and biodistribution which are very different from those of classical platinum compounds and might therefore be active against resistant human cancers $[3,5-8]$. In the last years three ruthenium(III) complexes entered clinical trials: NAMI-A - [ImH][trans$\left.\mathrm{RuCl}_{4}(\mathrm{DMSO})(\mathrm{Im})\right], \mathrm{KP} 1019$ - [InH] $\left[\right.$ trans $\left.-\mathrm{RuCl}_{4}(\mathrm{In})_{2}\right]$, and NKP3019 - Na[trans- $\left.\mathrm{RuCl}_{4}(\mathrm{In})_{2}\right]$ (In = indazole) [7, 9-12]. For recent developments on the anticancer activity of these ruthenium(III) complexes see cited references.

Previous work from our group displayed biological results from the diphosphonic ruthenium(II) precursors cis$\left[\mathrm{RuCl}_{2}(\mathrm{P}-\mathrm{P})_{2}\right], \mathrm{P}-\mathrm{P}=\mathrm{dppm}$ or dppe, and its derivatives with 2-pyridinecarboxylic acid anion (pic), the cis- $[\mathrm{Ru}(\mathrm{pic})(\mathrm{P}-$ $\left.\mathrm{P})_{2}\right] \mathrm{PF}_{6}$, with an $-N, O$ chelation for the pic ligand $[13,14]$. The antimycobacterial activity against $\mathrm{MTB}_{37} \mathrm{Rv}$ indicated a MIC value of $26.6 \mu \mathrm{M}$ for the precursor and a much higher activity for the cis- $\left[\mathrm{Ru}(\right.$ pic $\left.)(\mathrm{dppm})_{2}\right] \mathrm{PF}_{6}$ with a MIC 
value of $0.69 \mu \mathrm{M}$ [13]. Some additional studies performed with the analogous $c i s-\left[\mathrm{Ru}(\mathrm{pic})(\mathrm{dppe})_{2}\right] \mathrm{PF}_{6}$ revealed a high antibacterial activity against $S$. aureus, $C$. albicans, and $M$. smegmatis with MIC in the range 0.3 to $5.3 \mu \mathrm{M}$ [14]. In the assay of acute oral toxicity this complex belongs to class 5 (a substance with $\mathrm{LD}_{50}$ greater than 2000 and less than $5000 \mathrm{mg} \cdot \mathrm{kg}^{-1}$ body weight), indicating a relatively low acute toxicity [14]. Species containing bidentate carboxylates such as cis- $\left[\mathrm{Ru}(\mathrm{dicl})(\mathrm{dppm})_{2}\right] \mathrm{PF}_{6}, c i s-\left[\mathrm{Ru}(\mathrm{ibu})(\mathrm{dppm})_{2}\right] \mathrm{PF}_{6}$ and cis- $\left[\mathrm{Ru}(\right.$ prop$\left.)(\mathrm{dppe})_{2}\right] \mathrm{PF}_{6}$ were studied and presented moderate to high cytotoxic activity against human cancer cell lines $[15,16]$.

Due to this background of promising biological results in complexes containing the $c i s-\left[\mathrm{Ru}(\mathrm{P}-\mathrm{P})_{2}\right]$ unit our current strategy consists in evaluating other derivatives with different chelating moiety replacing the chlorido ligands in the search for new cytotoxic agents against tumor cells. In the current work quinoline carboxylates were chosen as coligands in order to generate cationic complexes and also to explore the possible different coordination modes of the ligands.

In this work the synthesis and characterization of two new derivatives with formula cis-[Ru(quin)(dppm $\left.)_{2}\right] \mathrm{PF}_{6}(\mathbf{1})$ and cis- $\left[\mathrm{Ru}(\mathrm{kynu})(\mathrm{dppm})_{2}\right] \mathrm{PF}_{6}(2)$ are reported. The interaction of these complexes with CT-DNA and BSA was investigated by circular dichroism (CD) and fluorescence spectroscopies, respectively. Besides, preliminary in vitro tests of cytotoxic activities against a variety of human cell lines are presented and discussed.

\section{Experimental}

2.1. Chemicals. Solvents were purified by standard methods. All chemicals used were of reagent grade or comparable purity. The $\mathrm{RuCl}_{3} \cdot 3 \mathrm{H}_{2} \mathrm{O}$ and the ligands 1,1-bis(diphenylphosphino)methane (dppm), quinaldic acid, and kynurenic acid were used as received from Aldrich. The cis$\left[\mathrm{RuCl}_{2}(\mathrm{dppm})_{2}\right]$ precursor complex was prepared according to the literature method [17].

2.2. Instrumentation. Elemental analyses were performed on a Perkin Elmer 2400 Series II CHNS/O microanalyser. Molar conductivities of freshly prepared $1.0 \times 10^{-3} \mathrm{~mol} \cdot \mathrm{dm}^{-3}$ methanol solutions were measured using a Digimed DM-31 conductivity meter. IR spectra were recorded on a Shimadzu FTIR-Prestige 21 spectrophotometer, using $\mathrm{KBr}$ pellets. UVvis spectroscopy was recorded on a Femto model $800 \mathrm{XI}$ spectrophotometer using cuvettes of $1 \mathrm{~cm}$ path length. ${ }^{1} \mathrm{H}$ and ${ }^{31} \mathrm{P}\left\{{ }^{1} \mathrm{H}\right\}$ NMR experiments were performed on a Bruker Avance III HD $400 \mathrm{MHz}(9.4 \mathrm{~T})$ at $298 \mathrm{~K}$. Spectra were recorded in $\mathrm{CDCl}_{3}$ with TMS and $85 \% \mathrm{H}_{3} \mathrm{PO}_{4}$ as external references, respectively, for ${ }^{1} \mathrm{H}$ and ${ }^{31} \mathrm{P}\left\{{ }^{1} \mathrm{H}\right\}$.

2.3. Synthesis. The precursor $c i s-\left[\mathrm{RuCl}_{2}(\mathrm{dppm})_{2}\right](0.103 \mathrm{mmol}$; $100 \mathrm{mg}$ ) was solubilized in $100 \mathrm{~mL}$ of methanol and the mixture was heated during 20 minutes. Quinaldic acid $(0.103 \mathrm{mmol} ; 17.8 \mathrm{mg})$ or kynurenic acid $(0.103 \mathrm{mmol}$; $19.5 \mathrm{mg}$ ), respectively, for synthesis of complexes $\mathbf{1}$ and $\mathbf{2}$, was solubilized in $10 \mathrm{~mL}$ of methanol and deprotonated with triethylamine $(0.132 \mathrm{mmol} ; 0.014 \mathrm{ml})$ and this solution was added dropwise on the precursor solution. After this processes, the mixture was stirred and refluxed for $48 \mathrm{~h}$. The final solution was concentrated to ca. $5 \mathrm{~mL}$ and an aqueous solution of $\mathrm{NH}_{4} \mathrm{PF}_{6}(0.150 \mathrm{mmol} ; 24.4 \mathrm{mg})$ was added for the precipitation of a yellow solid. The solid was filtered off and washed with water $(3 \times 5 \mathrm{~mL})$ and diethyl ether $(3 \times 5 \mathrm{~mL})$ and dried under reduced pressure.

2.3.1. cis-[Ru(quin) (dppm) $\left.{ }_{2}\right] P F_{6}$ (1). Yield: $79.1 \mathrm{mg}$ (63\%). Anal. Calcd for $\mathrm{C}_{60} \mathrm{H}_{50} \mathrm{~F}_{6} \mathrm{NO}_{2} \mathrm{P}_{5} \mathrm{Ru}$ : exptl (calc) $\mathrm{C}$, 60.97 (60.71); H, 4.93 (4.63); N, 1.10 (1.18). ${ }^{1} \mathrm{H}$ NMR $\left(\mathrm{CDCl}_{3}\right): \delta$ 4.11, $4.73\left(\mathrm{~m} \times 2,2 \times 2 \mathrm{H} ; \mathrm{PCH}_{2} \mathrm{P}\right), 6.26\left(\mathrm{~m}, 4 \mathrm{H} ; \mathrm{C}_{6} \mathrm{H}_{5}\right)$, 6.99-7.86 (m, 39H; $\mathrm{C}_{6} \mathrm{H}_{5}+$ quin), $7.91\left(\mathrm{~d}, J_{\mathrm{HH}}=8.1 \mathrm{~Hz}\right.$, $1 \mathrm{H}$; quin), $8.22\left(\mathrm{~d}, J_{\mathrm{HH}}=8.5 \mathrm{~Hz}, 1 \mathrm{H}\right.$; quin), $8.31\left(\mathrm{~d}, J_{\mathrm{HH}}=\right.$ $8.5 \mathrm{~Hz}, 1 \mathrm{H}$; quin) ppm. ${ }^{31} \mathrm{P}\left\{{ }^{1} \mathrm{H}\right\} \mathrm{NMR}\left(161.73 \mathrm{MHz}-\mathrm{CDCl}_{3}\right)$ : $\delta 9.70\left(\mathrm{t}, 2 \mathrm{P}, J_{\mathrm{PP}}=39 \mathrm{~Hz}\right) ;-12.2\left(\mathrm{t}, 2 \mathrm{P}, J_{\mathrm{PP}}=39 \mathrm{~Hz}\right) ;-144.7$ (sept, $1 \mathrm{P}, J_{\mathrm{PF}}=711 \mathrm{~Hz}$ ). UV-vis $\left(\mathrm{CH}_{2} \mathrm{Cl}_{2}, 5.0 \times 10^{-5} \mathrm{M}\right): \lambda / \mathrm{nm}$ $\left(\varepsilon / \mathrm{M}^{-1} \mathrm{~cm}^{-1}\right) 256 \mathrm{sh}\left(4.33 \times 10^{4}\right), 325\left(8.00 \times 10^{3}\right)$. Molar conductivity $\left[\Lambda_{\mathrm{M}} /\left(\mathrm{S} \cdot \mathrm{cm}^{2} \cdot \mathrm{mol}^{-1}\right)\right.$ in methanol: 79.0 (range for a 1:1 electrolyte: $80-115)$ [18].

2.3.2. cis-[Ru(kynu)(dppm) $\left.)_{2}\right] P F_{6}$ (2). Yield: $73.0 \mathrm{mg}$ (57\%). Anal. Calcd for $\mathrm{C}_{60} \mathrm{H}_{50} \mathrm{~F}_{6} \mathrm{NO}_{3} \mathrm{P}_{5} \mathrm{Ru}$ : exptl (calc) C, 59.87 (59.91); $\mathrm{H}, 4.68$ (4.39); $\mathrm{N}, 1.14(1.16) .{ }^{1} \mathrm{H} \mathrm{NMR}\left(\mathrm{CDCl}_{3}\right): \delta 4.14$, $4.73\left(\mathrm{~m} \times 2,2 \times 2 \mathrm{H} ; \mathrm{PCH}_{2} \mathrm{P}\right), 6.26\left(\mathrm{~m}, 4 \mathrm{H} ; \mathrm{C}_{6} \mathrm{H}_{5}\right), 6.80(\mathrm{~s}, 1 \mathrm{H}$; kynu), 6.96-7.77 (m, 39H; $\left.\mathrm{C}_{6} \mathrm{H}_{5}+\mathrm{kynu}\right), 8.37\left(\mathrm{~d}, \mathrm{~J}_{\mathrm{HH}}=7.7 \mathrm{~Hz}\right.$, $1 \mathrm{H}$; kynu), 8.62 (s, 1H; OH-kynu) ppm. ${ }^{31} \mathrm{P}\left\{{ }^{1} \mathrm{H}\right\} \mathrm{NMR}\left(\mathrm{CDCl}_{3}\right.$ - $161.73 \mathrm{MHz}): \delta(\mathrm{ppm}) 9.94\left(\mathrm{t}, 2 \mathrm{P}, J_{\mathrm{PP}}=39 \mathrm{~Hz}\right) ;-12.1\left(\mathrm{t}, 2 \mathrm{P}, J_{\mathrm{PP}}\right.$ $=39 \mathrm{~Hz}) ;-144.7$ (sept, $\left.1 \mathrm{P}, J_{\mathrm{PF}}=711 \mathrm{~Hz}\right)$. UV-vis $\left(\mathrm{CH}_{2} \mathrm{Cl}_{2}, 5.0\right.$ $\left.\times 10^{-5} \mathrm{M}\right): \lambda / \mathrm{nm}\left(\varepsilon / \mathrm{M}^{-1} \mathrm{~cm}^{-1}\right) 249 \mathrm{sh}\left(3.11 \times 10^{4}\right), 315 \mathrm{sh}(5.22$ $\left.\times 10^{3}\right), 329\left(7.10 \times 10^{3}\right), 344\left(7.4 \times 10^{3}\right), 363\left(4.01 \times 10^{3}\right)$. Molar conductivity $\left[\Lambda_{\mathrm{M}} /\left(\mathrm{S} \cdot \mathrm{cm}^{2} \cdot \mathrm{mol}^{-1}\right)\right.$ in methanol: 102.0 .

\subsection{Interactions Studies}

2.4.1. CT-DNA. Measurements involving CT-DNA (calf thymus from Sigma-Aldrich) were carried out in a Trizma buffer (4.5 mM Trizma HCl, $0.5 \mathrm{mM}$ Trizma base, and $50 \mathrm{mM}$ $\mathrm{NaCl}, \mathrm{pH}$ 7.4). The DNA concentration per nucleotide was determined by absorption spectrophotometric analysis using a molar absorption coefficient of $6600.0 \mathrm{~mol}^{-1} \cdot \mathrm{L} \cdot \mathrm{cm}^{-1}$ at $260.0 \mathrm{~nm}[19]$.

2.4.2. Circular Dichroism (CD) Experiments. CD spectra were recorded on a spectropolarimeter JASCO J-720 between 540 and $240 \mathrm{~nm}$ in a continuous scanning mode $\left(200 \mathrm{~nm} \cdot \mathrm{min}^{-1}\right)$. The final data are expressed in molar ellipticity (millidegrees). All of the CD spectra were generated and represented averages of three scans. Stock solutions of each complex were freshly prepared in DMSO prior to use. An appropriate volume of each solution was added to the samples of a freshly prepared solution of CT-DNA $(50 \mu \mathrm{M})$ in Trizma buffer to achieve molar ratios ranging from 0.05 to $0.5 \mathrm{DNA} \cdot \mathrm{drug}^{-1}$. The samples were incubated at $37^{\circ} \mathrm{C}$ for $18 \mathrm{~h}$.

2.4.3. BSA-Binding Experiments. The protein interaction with complexes $\mathbf{1}$ and $\mathbf{2}$ was examined in 96-well plates used for fluorescence assays on a fluorimeter Synergy H1. BSA 
$\left(2.0 \mu \mathrm{mol} \cdot \mathrm{L}^{-1}\right)$ was prepared in Trizma buffer at $\mathrm{pH}=7.4$ (4.5 mM Trizma HCl, $0.5 \mathrm{mM}$ Trizma base and $50 \mathrm{mM} \mathrm{NaCl}$ ).

The inner-filter effect for ruthenium complexes was corrected by using

$$
F_{\text {corr }}=F_{\text {obs }} e^{\left(A_{\mathrm{em}}+A_{\mathrm{ex}}\right) / 2}
$$

where $F_{\text {corr }}$ and $F_{\text {obs }}$ are the corrected and measured fluorescence intensity of protein, respectively. $A_{\mathrm{em}}$ and $A_{\mathrm{ex}}$ are the absorption values of the system at the excitation wavelength and emission wavelength of the complex, respectively.

Complexes were dissolved in sterile DMSO. For fluorescence measurements, the BSA concentration was kept constant in all samples, while the complex concentration was increased from 3.125 to $150 \mu \mathrm{M}$, and quenching of the emission intensity of the tryptophan residues of BSA at $320 \mathrm{~nm}$ (excitation wavelength $280 \mathrm{~nm}$ ) was monitored at different temperatures ( 300 and $310 \mathrm{~K}$ ). The experiments were carried out in triplicate and analyzed using the classical SternVolmer equation

$$
\frac{F_{0}}{F}=1+k_{q} \tau_{o}[Q]=1+K_{\mathrm{sv}}[Q]
$$

where $F_{0}$ and $F$ are the fluorescence intensities in the absence and presence of quencher, respectively, [Q] is the quencher concentration, and $K_{\mathrm{sv}}$ is the Stern-Volmer quenching constant, which can be written as

$$
K_{q}=\frac{K_{\mathrm{sv}}}{\tau_{o}},
$$

where $K_{q}$ is the biomolecular quenching rate constant and $\tau_{o}$ is the average lifetime of the fluorophore in the absence of quencher $\left(6.2 \times 10^{-9} \mathrm{~s}\right)$ [20]. Therefore, (2) was applied to determine $K_{\mathrm{sv}}$ by linear regression of a plot of $F_{0} / F$ versus [Q].

The binding constant $\left(K_{b}\right)$ and number of complexes bound to BSA $(n)$ were determined by plotting the double log graph of the fluorescence data using

$$
\log \frac{\left(F_{0}-F\right)}{F}=\log K_{b}+n \log [\mathrm{Q}]
$$

The thermodynamic parameters were calculated from the van't Hoff equation:

$$
\ln K_{b}=\frac{\Delta H^{\circ}}{R T}+\frac{\Delta S^{\circ}}{R}
$$

where $K_{b}$ is analogous to the Stern-Volmer quenching constant, $K_{\mathrm{sv}}$ is at the corresponding temperature (the temperatures used were 300 and $310 \mathrm{~K}$ ), and $R$ is the gas constant, from which the $\Delta H$ and $\Delta S$ of the reaction can be determined from the linear relationship between $\ln K_{b}$ and the reciprocal absolute temperature. Furthermore, the change in free energy $(\Delta G)$ was calculated from the following equation:

$$
\Delta G^{\circ}=-R T \ln K_{b}=\Delta H^{\circ}-T \Delta S^{\circ} .
$$

2.5. Human Cell Lines and Culture Conditions. Cells from the 4 th through to the 12 th passage were used. The different cell lines were maintained as monolayers in plastic culture flasks $\left(25 \mathrm{~cm}^{2}\right)$ containing HAM-F10 plus DMEM (1:1; Sigma-Aldrich) or only DMEM depending on the cell line, supplemented with $10 \%$ fetal bovine serum (Nutricell) and $2.38 \mathrm{mg} \cdot \mathrm{mL}^{-1}$ Hepes (Sigma-Aldrich) at $37^{\circ} \mathrm{C}$ in a humidified $5 \% \mathrm{CO}_{2}$ atmosphere. Antibiotics $\left(0.01 \mathrm{mg} \cdot \mathrm{mL}^{-1}\right.$ streptomycin and $0.005 \mathrm{mg} \cdot \mathrm{mL}^{-1}$ penicillin; Sigma-Aldrich) were added to the medium to prevent bacterial growth.

2.6. Cell Viability Assay. The screening for cytotoxic activity of cell lines was assessed using the Colorimetric Assay In Vitro Toxicology-XTT Kit (Roche Diagnostics). For the experiments, $1 \times 10^{4}$ cells were seeded into microplates with $100 \mu \mathrm{L}$ of culture medium (1:1 HAM F10 + DMEM or alone DMEM) supplemented with $10 \%$ fetal bovine serum containing concentrations of complexes ranging from 12.5 to $1600 \mu \mathrm{g} \cdot \mathrm{mL}^{-1}$. Negative (no treatment), solvent $(0.02 \%$ DMSO), and positive (25\% DMSO) controls were included. Positive controls comprising cisplatin (Sigma-Aldrich, $\geq 98 \%$ purity) were included. After incubation to $36.5^{\circ} \mathrm{C}$ for $24 \mathrm{~h}$, the culture medium was removed. Cells were washed with $100 \mu \mathrm{L}$ of PBS for removal of the treatments, after which they were exposed to $100 \mu \mathrm{L}$ of culture medium HAM-F10 without phenol red. Then, $25 \mu \mathrm{L}$ of XTT was added and incubated at $36.5^{\circ} \mathrm{C}$ for $17 \mathrm{~h}$. The absorbance of the samples was determined using a multiplate reader (ELISA-Tecan-SW Magellan versus 5.03 STD 2P) at a wavelength of $450 \mathrm{~nm}$ and a reference length of $620 \mathrm{~nm}$.

2.7. Statistical Analysis. Cytotoxicity was assessed using the $\mathrm{IC}_{50}$ response parameter (50\% cell growth inhibition) calculated with the GraphPad Prism program, plotting cell survival against the respective concentrations of the treatments. Oneway ANOVA was used for the comparison of means $(P<$ 0.05). The selectivity index was calculated by dividing the $\mathrm{IC}_{50}$ value of the isolated compounds on GM07492-A cells by the $\mathrm{IC}_{50}$ value determined for human cancer cells.

\section{Results and Discussion}

3.1. Synthesis. The simple reaction of the quinoline carboxylic acids with ruthenium(II) diphosphine precursor complex cis- $\left[\mathrm{RuCl}_{2}(\mathrm{dppm})_{2}\right]$ resulted in the products cis$\left[\mathrm{Ru}(\right.$ quin $\left.)(\mathrm{dppm})_{2}\right] \mathrm{PF}_{6}$ (1) and cis- $\left[\mathrm{Ru}(\mathrm{kynu})(\mathrm{dppm})_{2}\right] \mathrm{PF}_{6}$ (2), Figure 1, by simple chlorido exchange under mild conditions.

3.2. Spectroscopical Characterization. The diamagnetic and monoelectrolytes compounds 1-2 exhibited satisfactory microanalytical $(\mathrm{C}, \mathrm{H}$, and $\mathrm{N})$ data. The ${ }^{1} \mathrm{H}$ NMR spectra showed two broad signals due to the $\mathrm{CH}_{2}$ group of the dppm ligand close to 4.10 and $4.70 \mathrm{ppm}$ [21]. The hydrogens of the phenyl groups $\left(\mathrm{H}_{\mathrm{o}}, \mathrm{H}_{\mathrm{m}}\right.$ and $\left.\mathrm{H}_{\mathrm{p}}\right)$ were observed as several multiplets between 6.26 and 7.86 ppm [21]. For complex 1 three doublets of the quin ligand were observed at 7.91, 8.22, and $8.31 \mathrm{ppm}$ while for complex 2 one doublet at $8.37 \mathrm{ppm}$ and two singlet signals at 6.80 and $8.62 \mathrm{ppm}$ 


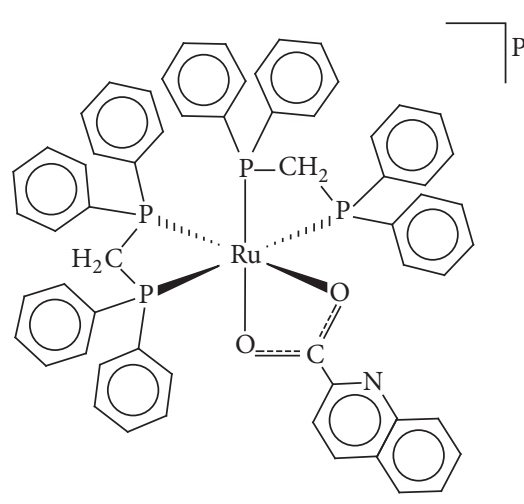

1

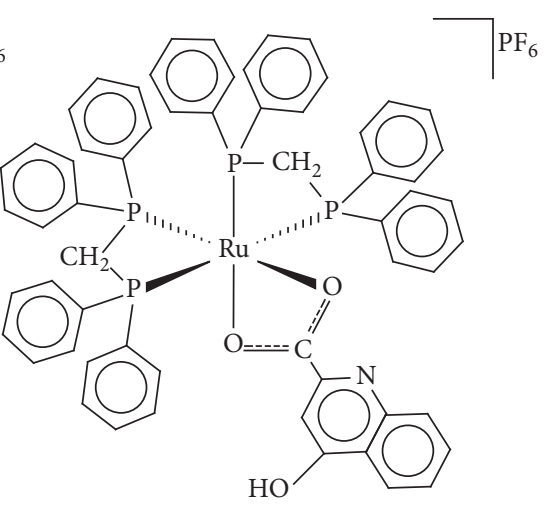

2

FIGURE 1: Structures of the ruthenium(II) compounds obtained in this work.

could be assigned to the kynu ligand [22]. Other hydrogens of the quin and kynu ligands were obscured by the signals corresponding to the hydrogens of the phenyl groups. The total number of hydrogens and proportion between the ligands dppm and quin or kynu was confirmed by the integral values for both complexes. In the ${ }^{31} \mathrm{P}\left\{{ }^{1} \mathrm{H}\right\}$ NMR spectra these complexes displayed a pair of triplets resonance signals, corresponding to two transpositioned phosphorus atoms and two phosphorus atoms transpositioned to oxygen atoms from carboxylate groups of the quinaldate and kynurenate anions, respectively. Triplets are observed at 9.70 and $-12.2 \mathrm{ppm}$ and at 9.94 and $-12.1 \mathrm{ppm}$, respectively, for $\mathbf{1}$ and 2, with the splitting pattern typical of an AX pattern [16]. These signals are downfield shifted when compared with the triplets signals for the $c i s-\left[\mathrm{RuCl}_{2}(\mathrm{dppm})_{2}\right]$ that are observed at 0.64 and $-25.3 \mathrm{ppm}$ with $J_{\mathrm{PP}}=36 \mathrm{~Hz}$ [17].

The IR spectrum displayed the typical asymmetric $\left(v_{\text {asym }}\right)$ and symmetric $\left(v_{\text {sym }}\right)$ carboxylate stretching frequencies at 1523 and $1455 \mathrm{~cm}^{-1}\left(\Delta=68 \mathrm{~cm}^{-1}\right)$ and 1516 and $1454(\Delta=$ $62 \mathrm{~cm}^{-1}$ ), respectively, for 1 and 2 , confirming the presence of the quinoline carboxylate ligands coordinated in the chelating mode through the carboxylate to the metal center $[23,24]$. The characteristic $\mathrm{P}-\mathrm{F}$ stretch of the $\mathrm{PF}_{6}{ }^{-}$counterion was seen at 840 and $557 \mathrm{~cm}^{-1}$ [23].

3.3. Circular Dichroism (CD) Experiments. The CD spectral technique is very sensitive for diagnosing changes in the secondary structure of DNA, resulting from drug-DNA interactions [25]. A typical CD spectrum of CT-DNA shows a maximum at $275 \mathrm{~nm}$, due to the base-stacking and a minimum at $248 \mathrm{~nm}$ attributed to the right-handed helicity, characteristic of the B conformation [26]. Thus simple groove binding and electrostatic interaction of small molecules show less or no perturbation on the base-stacking and helicity bands, while intercalation enhances the intensities of both the bands stabilizing the right-handed $\mathrm{B}$ conformation of CT-DNA as observed for the classical intercalator methylene blue [27]. To determine if the ruthenium(II) complexes cause changes in DNA, CD spectra of CT-DNA with increasing concentrations of $\mathbf{1}$ and $\mathbf{2}$ were acquired, up to molar ratio drug. $\mathrm{DNA}^{-1}(\mathrm{Ri})=0.4$. As shown in Figure 2 significant changes were not observed indicating that these compounds were not able to intercalate DNA [28].

3.4. BSA-Binding Experiments. Serum albumin is the most abundant protein in plasma and is involved in the transport of metal ions and metal complexes with drugs through the blood stream. Binding to these proteins to complexes may lead to loss or conformational change in the protein subunit and provide paths for drug transportation. Bovine serum albumin, BSA (containing two tryptophans, Trp-134 and Trp212 ) is the most extensively studied serum albumin, due to its structural homology with human serum albumin, HAS (one Trp-214). The BSA solution exhibits a strong fluorescence emission with a peak at $340 \mathrm{~nm}$, due to the tryptophan residues, when excited at $280 \mathrm{~nm}$ [29]. Fluorescence quenching of BSA can occur by different mechanisms, usually classified as either dynamic or static quenching, which can be distinguished by their differing on temperature, viscosity, and lifetime measurements [30]. A dynamic quenching refers to the collisional process between the fluorophore and the quencher (in this case, ruthenium complexes) during the transient existence of the excited state. Dynamic quenching depends on diffusion, as higher temperatures result in high diffusion coefficient, and consequently, the constant quenching must also increase. In contrast, for the static quenching, an increase in temperature results in lower extinction values of the constants due to a fluorophore and quencher complex formation in the ground state [31].

The Stern-Volmer equation (2) has been used to understand the nature of the quenching mechanism of BSA in the presence of complexes $\mathbf{1}$ and $\mathbf{2}$ at different temperatures [31]. Figure 3 shows the quenching of the BSA in the presence of the different concentrations of the complexes $\mathbf{1}$ and $\mathbf{2}$.

In general, these complexes showed no significant variation $K_{\mathrm{sv}}$ with increasing temperature. However, the results of $K_{q}$ have values greater than the maximum possible for a dynamic mechanism $\left(2.0 \times 10^{10} \mathrm{~L} \cdot \mathrm{mol}^{-1} \cdot \mathrm{s}^{-1}\right)$ [32] and in both cases were of the order $10^{13} \mathrm{M}^{-1} \cdot \mathrm{s}^{-1}$ (Table 1), which is 1000 -fold higher than the maximum value possible for diffusion controlled quenching of various kinds of quencher to biopolymer. It is suggested that the suppression of BSA 


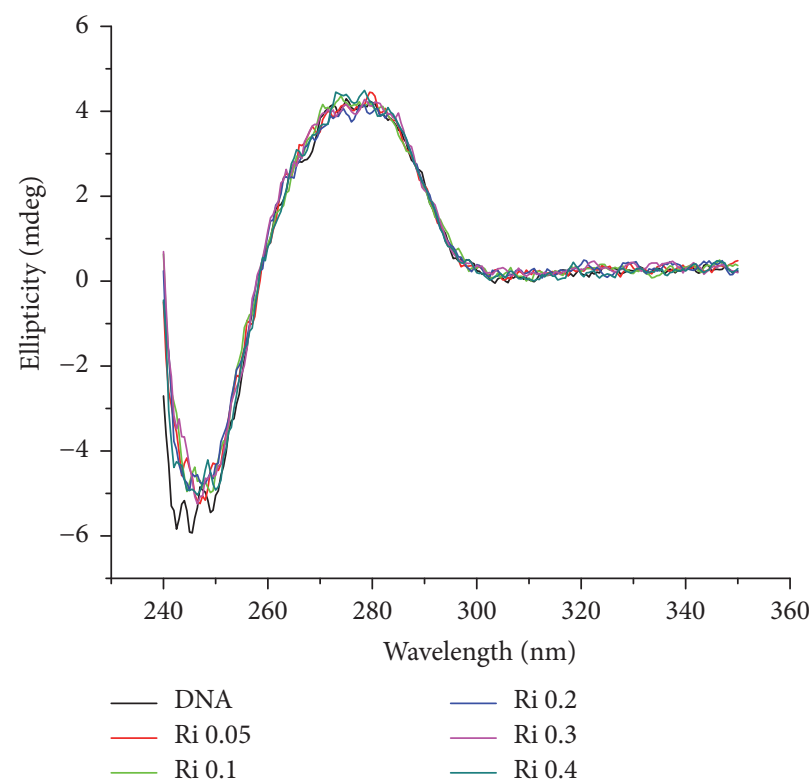

(a)

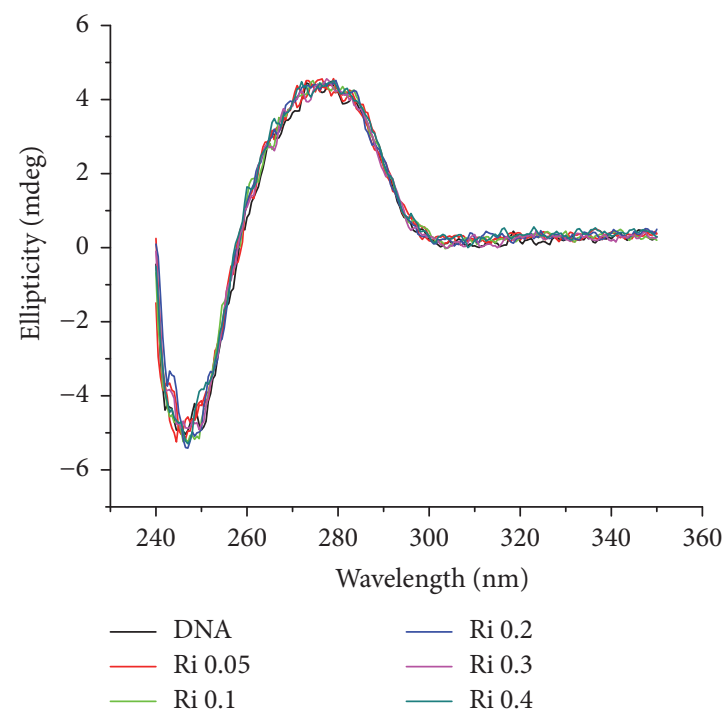

(b)

FiguRE 2: Circular dichroism (CD) spectra of CT-DNA incubated $18 \mathrm{~h}$ with complexes $\mathbf{1}$ (a) and $\mathbf{2}$ (b) at different [complex]/[DNA] ratios at $37^{\circ} \mathrm{C}$.

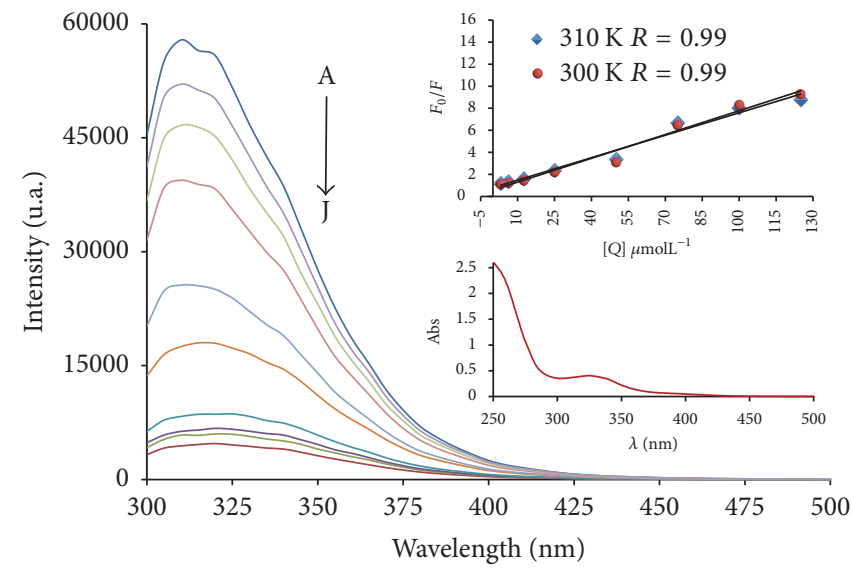

(a)

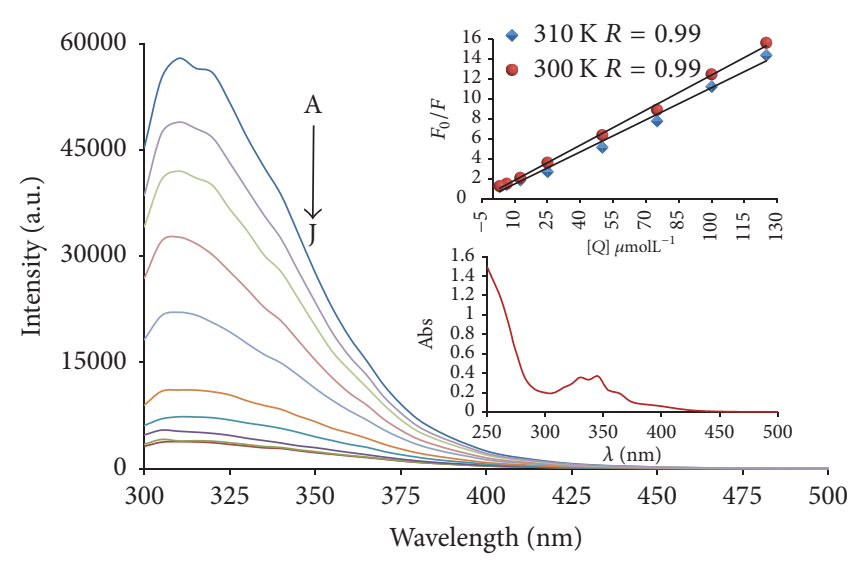

(b)

FIGURE 3: Fluorescence emission spectra of the BSA $\left(2.5 \mu \mathrm{M} \lambda_{\text {ex }} 280 \mathrm{~nm}\right.$ ) at different concentrations of complexes $\mathbf{1}$ (a) and 2 (b) at $300 \mathrm{~K}$. Inset: Stern-Volmer plots showing tryptophan quenching in BSA at 300 and $310 \mathrm{~K}$ and UV-vis spectra of complexes $\mathbf{1}$ and 2.

with these complexes is a static quenching mechanism. The decreasing of $K_{q}$ with increasing temperature is in accordance with $K_{\mathrm{sv}}$ dependence on temperature.

In both cases, the obtained values of $n$ indicate that the proportion between BSA-complex is equal 1:1, indicating that there is only one binding site in the BSA for each ruthenium complex, similar or equal to those reported before for other metal complexes [33-35]. Furthermore, values of $K_{b}$ confirmed the moderated interaction force between complex-BSA [36-38] and the temperature is not significant. Thus, these complexes can be stored and carried by protein in the body. The interaction forces between drugs and biomolecules may include van der Waals interaction, hydrogen bonds, and electrostatic and hydrophobic interactions. The thermodynamic parameters $\Delta G$ (free energy change), $\Delta H$ (enthalpy change), and $\Delta S$ (entropy change) were calculated to evaluate the intermolecular forces involving the molecules of complex and BSA. The values for $\Delta H>0$ and $\Delta S$ $>0$ imply the involvement of hydrophobic forces in protein binding, $\Delta H<0$ and $\Delta S<0$ correspond to van der Waals and hydrogen bonding interactions, and $\Delta H<0$ and $\Delta S>0$ suggest an electrostatic force [39]. Thermodynamic parameters ( $\Delta H$ and $\Delta S$ ) were calculated from the van't Hoff plots, (5); $\Delta G$ was estimated from (6). All the results are shown in Table 1. 
TABLE 1: Stern-Volmer quenching constant $\left(K_{\mathrm{sv}}, \mathrm{L} \cdot \mathrm{mol}^{-1}\right)$, biomolecular quenching rate constant $\left(K_{q}, \mathrm{~L} \cdot \mathrm{mol}^{-1} \cdot \mathrm{s}^{-1}\right)$, binding $\mathrm{constant}\left(K_{b}\right.$, $\left.\mathrm{L} \cdot \mathrm{mol}^{-1}\right)$, the number of binding sites $(n)$, and $\Delta G^{0}\left(\mathrm{KJ} \cdot \mathrm{mol}^{-1}\right), \Delta H^{0}\left(\mathrm{KJ} \cdot \mathrm{mol}^{-1}\right)$, and $\Delta S^{0}\left(\mathrm{~J} \cdot \mathrm{mol}^{-1} \cdot \mathrm{K}\right)$ values for the complex-BSA system at different temperatures.

\begin{tabular}{ccccccrr}
\hline & $\begin{array}{c}K_{\text {sv }} \\
\left(\times 10^{5}\right)\end{array}$ & $\begin{array}{c}K_{q} \\
\left(\times 10^{13}\right)\end{array}$ & $\begin{array}{c}K_{b} \\
\left(\times 10^{5}\right)\end{array}$ & $n$ & $\Delta G^{0}$ & $\Delta H^{0}$ & $\Delta S^{0}$ \\
\hline \multirow{1}{*}{2} & 300 & 0.77 & 1.10 & 4.77 & 1.2 & -32.61 & -87.78 \\
& 310 & 0.75 & 1.10 & 1.53 & 1.0 & -30.77 & -183.91 \\
& 300 & 1.24 & 1.79 & 3.25 & 1.1 & -31.65 & -50.16 \\
\hline
\end{tabular}

TABLE 2: Inhibitory activity of ruthenium complexes and cisplatin against normal and tumor cell lines for $24 \mathrm{~h}$ incubation, expressed as $\mathrm{IC}_{50}$, $\mu \mathrm{g} \cdot \mathrm{mL}^{-1}(\mu \mathrm{M})$ and selectivity index (SI).

\begin{tabular}{|c|c|c|c|c|c|c|c|}
\hline & \multicolumn{7}{|c|}{ Cell line } \\
\hline & $\mathrm{HepG}^{\mathrm{a}}$ & MCF-7 $7^{b}$ & MO59J $^{c}$ & GM07492A ${ }^{\mathrm{d}}$ & $\mathrm{SI}^{1}$ & $\mathrm{SI}^{2}$ & $\mathrm{SI}^{3}$ \\
\hline$c i s-\left[\mathrm{RuCl}_{2}(\mathrm{dppm})_{2}\right]$ & $\begin{array}{c}102 \pm 26 \\
(108 \pm 26)\end{array}$ & $\begin{array}{c}180 \pm 13 \\
(191 \pm 13)\end{array}$ & $\begin{array}{c}126 \pm 10 \\
(134 \pm 10)\end{array}$ & $\begin{array}{c}62 \pm 4 \\
(66 \pm 4)\end{array}$ & 0.61 & 0.34 & 0.49 \\
\hline 1 & $\begin{array}{c}11.8 \pm 0.7 \\
(10.1 \pm 0.6)\end{array}$ & $\begin{array}{c}14.2 \pm 0.6 \\
(12.1 \pm 0.5)\end{array}$ & $\begin{array}{c}13 \pm 2 \\
(11 \pm 2)\end{array}$ & $\begin{array}{c}11 \pm 1 \\
(10 \pm 1)\end{array}$ & 0.93 & 0.77 & 0.85 \\
\hline 2 & $\begin{array}{c}31 \pm 6 \\
(26 \pm 5)\end{array}$ & $\begin{array}{c}162 \pm 14 \\
(135 \pm 11)\end{array}$ & $\begin{array}{c}44 \pm 3 \\
(36 \pm 2)\end{array}$ & $\begin{array}{c}45 \pm 1 \\
(37 \pm 1)\end{array}$ & 1.45 & 0.28 & 1.02 \\
\hline cisplatin $^{\mathrm{e}}$ & $\begin{array}{c}1.9 \pm 0.2 \\
(6.3 \pm 0.7)\end{array}$ & $\begin{array}{c}10 \pm 1 \\
(34 \pm 4)\end{array}$ & $\begin{array}{c}7 \pm 1 \\
(22 \pm 4)\end{array}$ & $\begin{array}{c}8 \pm 1 \\
(26 \pm 3)\end{array}$ & 4.21 & 0.80 & 1.14 \\
\hline
\end{tabular}

${ }^{\mathrm{a}}$ Human hepatocellular carcinoma, ${ }^{\mathrm{b}}$ human breast adenocarcinoma, ${ }^{c}$ human glioblastoma, ${ }^{\mathrm{d}}$ normal human lung fibroblasts, and ${ }^{\mathrm{e}}$ reference drug. $\mathrm{SI}^{1}=\mathrm{IC}_{50}$ GM07492A/IC ${ }_{50}$ HepG2; SI $^{2}=$ IC $_{50}$ GM07492A/IC ${ }_{50}$ MCF-7; SI $^{3}=$ IC $_{50}$ GM07492A/IC ${ }_{50}$ MO59J.

The negative values of free energy, $\Delta G$, suggested that the interaction process was spontaneous; the values entropy $\Delta S$ and enthalpy $\Delta H$ negative indicated that the hydrogen bonds and van der Waals forces are the more important interactions in the reaction [38].

3.5. Cytotoxicity Assays. Ruthenium compounds $\mathbf{1}$ and $\mathbf{2}$, cis- $\left[\mathrm{RuCl}_{2}(\mathrm{dppm})_{2}\right]$ and cisplatin were evaluated for their capability of inhibiting tumor cell growth in vitro using three human cell lines, HepG2, MCF-7, and MO59J. One nontumorigenic cell line (GM07492A) was also assayed in the same conditions in order to verify the selectivity of these compounds. The resulting concentration-effect curves obtained with continuous exposure for $24 \mathrm{~h}$ are depicted in Figure 4. A more convenient comparison of the cytotoxic potency (expressed as $\mathrm{IC}_{50}$ values) is listed in Table 2 .

Overall sensitivities of the three tumor cell lines (Figures $4(\mathrm{a})-4(\mathrm{c})$ ) and of the normal cell (Figure $4(\mathrm{~d})$ ) are more pronounced for complex 1 , followed by complex 2 , and the less active is the precursor cis- $\left[\mathrm{RuCl}_{2}(\mathrm{dppm})_{2}\right]$.

Complexes $\mathbf{1}$ and $\mathbf{2}$ have showed, in general, a moderate cytotoxicity against all the human tumor cell lines assayed with $\mathrm{IC}_{50}$ values ranging from 10.1 to $36 \mu \mathrm{M}$, except for complex 2 in MCF-7 cells that showed a very low cytotoxicity as shown in Table 2. Complex 1 displayed higher activity than $\mathbf{2}$ in all the cell lines assayed with $\mathrm{IC}_{50}$ close to $10 \mu \mathrm{M}$. This nonselective activity of complex 1 was not observed for complex 2 that was almost inactive in MCF-7 cells. The selectivity index (SI) was very close to 1 (or smaller) for all the cell lines assayed indicating a lack of selectivity for both complexes.
In the same experimental conditions the precursor complex cis- $\left[\mathrm{RuCl}_{2}(\mathrm{dppm})_{2}\right]$ was less active than the complexes $\mathbf{1}$ and 2 by factors ranging from 1.4 to 15.8 . A similar increased in activity was also observed against the normal cell line GM07492A. This lack of selectivity was also observed for the cis- $\left[\mathrm{RuCl}_{2}(\mathrm{dppm})_{2}\right]$ for all the cell lines assayed and for cisplatin in the MCF-7 and MO59J cell lines. These data clearly indicate that exchanging two chlorido ligands by a bidentate quinoline carboxylate group turns the unity cis$\left[\mathrm{Ru}(\mathrm{dppm})_{2}\right]$ complex more cytotoxic, probably due to its higher solubility and disponibility in the culture medium. Interestingly, the presence of one $\mathrm{OH}$-group in complex 2 led to a significant decrease in cytotoxic activity, indicating that this may be a way to modulate the cytotoxic potency of this type of complex.

\section{Conclusion}

In this investigation two new ruthenium(II) complexes containing dppm and the quinaldate and kynurenate anions with formula cis-[Ru(quin)(dppm $\left.)_{2}\right] \mathrm{PF}_{6}$ and cis$\left[\mathrm{Ru}(\mathrm{kynu})(\mathrm{dppm})_{2}\right] \mathrm{PF}_{6}$ were synthesized and characterized by elemental analysis and spectroscopic methods. Characterization data are in agreement with a cis geometry and a chelated coordination, through the carboxylate group, for the quinaldate and kynurenate ligands. Utilizing circular dichroism spectroscopy showed that these complexes lack the ability to intercalate DNA. On the other hand BSA-binding constants and thermodynamic parameters suggest spontaneous interactions with this protein by hydrogen bonds and van der 


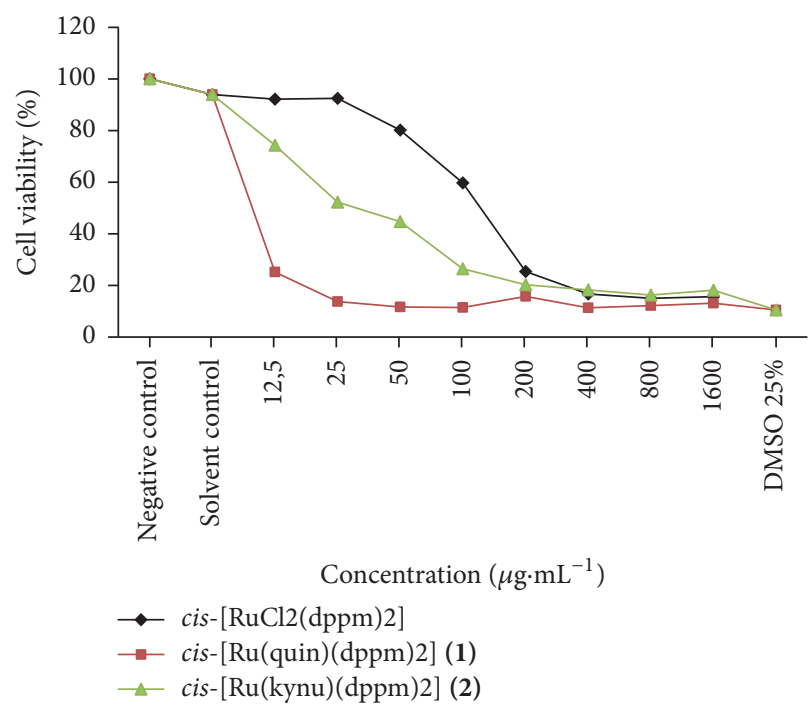

(a)

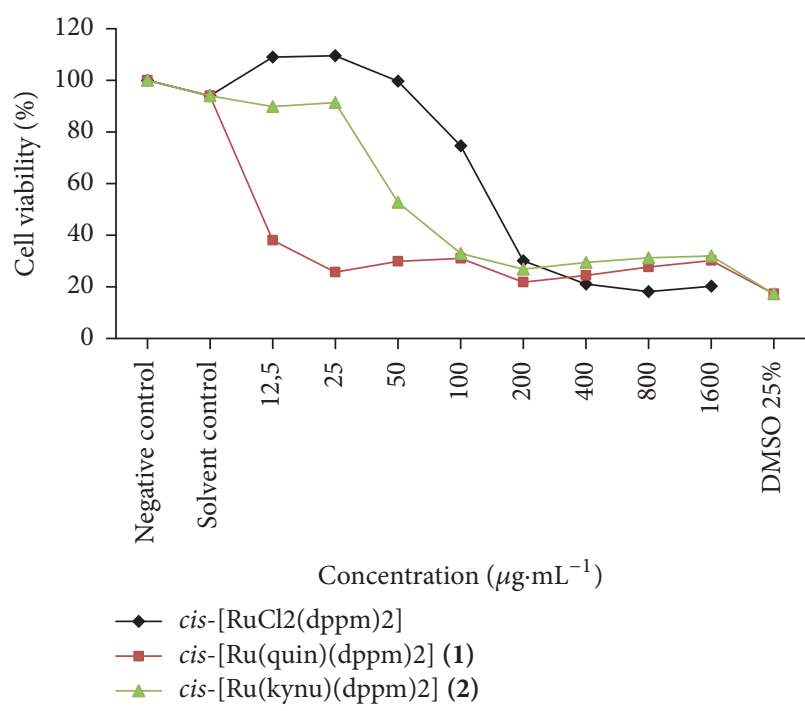

(c)

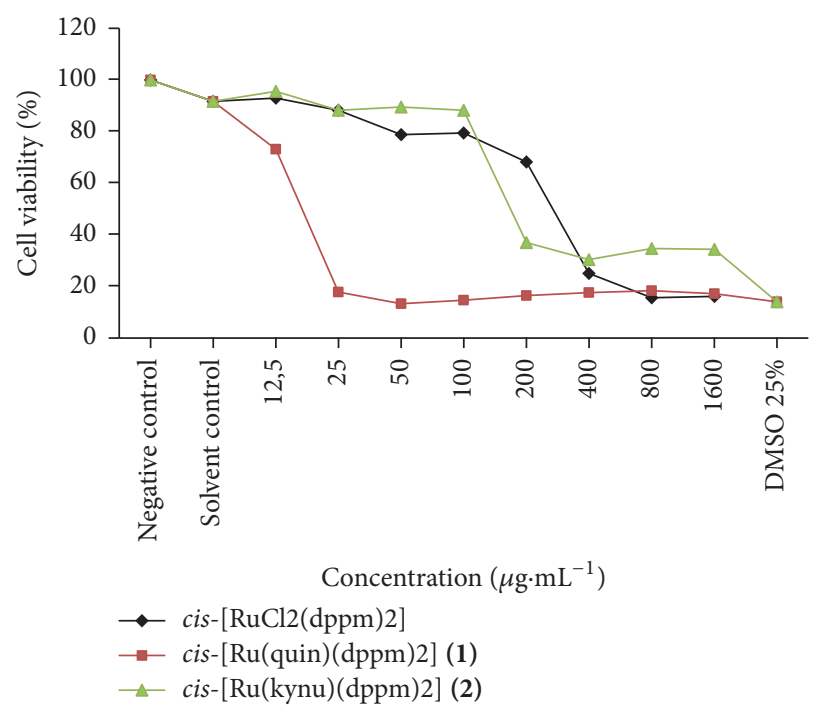

(b)

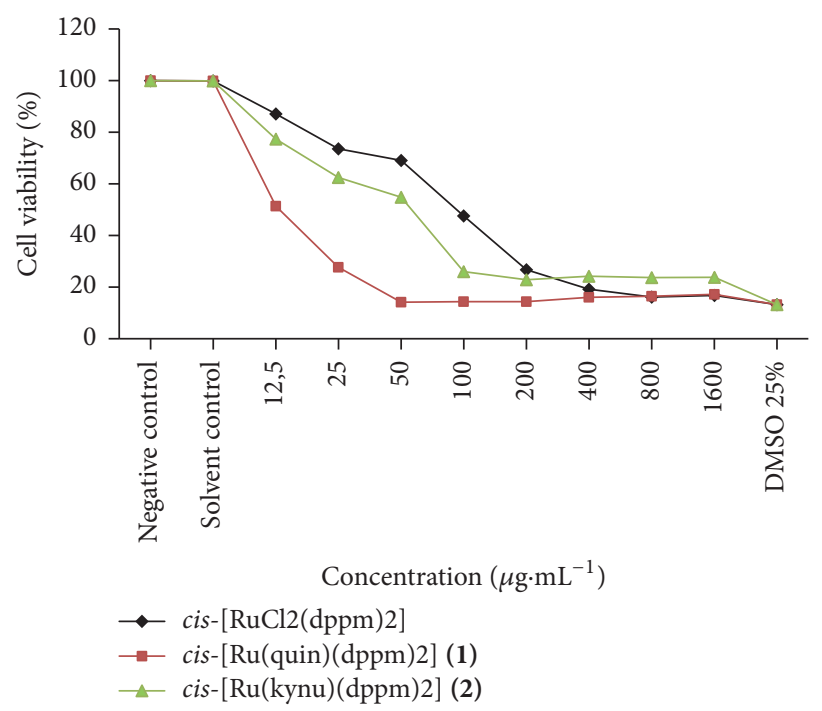

(d)

FIGURE 4: In vitro cytotoxicity activities of ruthenium complexes in HepG2 (a), MCF-7 (b), MO59J (c), and GM07492A (d) cells after exposure for $24 \mathrm{~h}$. The concentration-effect curves were determined using XTT assay. Each data point is the mean \pm standard error obtained from three independent experiments.

Waals forces. The in vitro cytotoxicity activity assays indicate a moderate to high cytotoxicity against a panel of human tumor cell lines; however, these complexes lacks selectivity. Interestingly, modulation of cytotoxic potency can probably be done by exchanging the substituents of the quinolone carboxylate ligand and will be explored in future work.

\section{Conflicts of Interest}

The authors declare that there are no conflicts of interest regarding the publication of this paper.

\section{Acknowledgments}

This work was supported by Fundação de Amparo à Pesquisa de Minas Gerais (FAPEMIG) (Grant APQ-04010-10),
CAPES, and CNPq. Gustavo Von Poelhsitz is thankful to the Grupo de Materiais Inorgânicos do Triângulo-GMIT research group supported by FAPEMIG (APQ-00330-14) and Rede Mineira de Química (RQ-MG) supported by FAPEMIG (Project: CEX - RED-00010-14).

\section{References}

[1] S. Dasari and P. B. Tchounwou, "Cisplatin in cancer therapy: molecular mechanisms of action," European Journal of Pharmacology, vol. 740, pp. 364-378, 2014.

[2] N. J. Wheate, S. Walker, G. E. Craig, and R. Oun, "The status of platinum anticancer drugs in the clinic and in clinical trials," Dalton Transactions, vol. 39, no. 35, pp. 8113-8127, 2010.

[3] K. D. Mjos and C. Orvig, "Metallodrugs in medicinal inorganic chemistry," Chemical Reviews, vol. 114, no. 8, pp. 4540-4563, 2014. 
[4] S. Gómez-Ruiz, D. Maksimović-Ivanić, S. Mijatović, and G. N. Kaluđerović, "On the discovery, biological effects, and use of cisplatin and metallocenes in anticancer chemotherapy," Bioinorganic Chemistry and Applications, vol. 2012, Article ID 140284, 14 pages, 2012.

[5] C. G. Hartinger, S. Zorbas-Seifried, M. A. Jakupec, B. Kynast, H. Zorbas, and B. K. Keppler, "From bench to bedside - preclinical and early clinical development of the anticancer agent indazolium trans-[tetrachlorobis(1H-indazole)ruthenate(III)] (KP1019 or FFC14A)," Journal of Inorganic Biochemistry, vol. 100, no. 5-6, pp. 891-904, 2006.

[6] W. H. Ang, A. Casini, G. Sava, and P. J. Dyson, "Organometallic ruthenium-based antitumor compounds with novel modes of action," Journal of Organometallic Chemistry, vol. 696, no. 5, pp. 989-998, 2011.

[7] A. Bergamo, C. Gaiddon, J. H. Schellens, J. H. Beijnen, and G. Sava, "Approaching tumour therapy beyond platinum drugs: status of the art and perspectives of ruthenium drug candidates," Journal of Inorganic Biochemistry, vol. 106, no. 1, pp. 90-99, 2012.

[8] V. Moreno, J. Lorenzo, F. X. Aviles et al., "Studies of the antiproliferative activity of ruthenium (II) Cyclopentadienyl-derived complexes with nitrogen coordinated ligands," Bioinorganic Chemistry and Applications, vol. 2010, Article ID 936834, 11 pages, 2010.

[9] S. Pillozzi, L. Gasparoli, M. Stefanini et al., "NAMI-A is highly cytotoxic toward leukaemia cell lines: Evidence of inhibition of KCa 3.1 channels," Dalton Transactions, vol. 43, no. 32, pp. 12150-12155, 2014.

[10] R. Trondl, P. Heffeter, C. R. Kowol, M. A. Jakupec, W. Berger, and B. K. Keppler, "NKP-1339, the first ruthenium-based anticancer drug on the edge to clinical application," Chemical Science, vol. 5, no. 8, pp. 2925-2932, 2014.

[11] C. G. Hartinger, M. A. Jakupec, S. Zorbas-Seifried et al., "KP1019, a new redox-active anticancer agent-preclinical development and results of a clinical phase I study in tumor patients," Chemistry and Biodiversity, vol. 5, no. 10, pp. 21402155, 2008.

[12] M. Oszajca, E. Kuliś, G. Stochel, and M. Brindell, "Interaction of the NAMI-A complex with nitric oxide under physiological conditions," New Journal of Chemistry, vol. 38, no. 8, pp. 33863394, 2014.

[13] F. R. Pavan, G. V. Poelhsitz, F. B. do Nascimento et al., "Ruthenium (II) phosphine/picolinate complexes as antimycobacterial agents," European Journal of Medicinal Chemistry, vol. 45, no. 2, pp. 598-601, 2010.

[14] F. R. Pavan, G. V. Poelhsitz, L. V. P. da Cunha et al., "In vitro and in vivo activities of ruthenium(II) phosphine/diimine/ picolinate complexes (SCAR) against Mycobacterium tuberculosis," PLoS ONE, vol. 8, no. 5, Article ID e64242, 2013.

[15] T. M. P. Pagoto, L. L. G. Sobrinho, A. E. Graminha et al., "A ruthenium(II) complex with the propionate ion: Synthesis, characterization and cytotoxic activity," Comptes Rendus Chimie, vol. 18, no. 12, pp. 1313-1319, 2015.

[16] J. C. S. Lopes, J. L. Damasceno, P. F. Oliveira et al., "Ruthenium(II) Complexes containing anti-inflammatory drugs as ligands: synthesis, characterization and in vitro cytotoxicity activities on cancer cell lines," Journal of the Brazilian Chemical Society, vol. 26, no. 9, pp. 1838-1847, 2015.

[17] B. P. Sullivan and T. J. Meyer, "Comparisons of the physical and chemical properties of isomeric pairs. 2. Photochemical, thermal, and electrochemical cis-trans isomerizations of
$\mathrm{M}(\mathrm{Ph} 2 \mathrm{PCH} 2 \mathrm{PPh} 2) 2 \mathrm{Cl} 2$ (M = RuII, OsII)," Inorganic Chemistry, vol. 21, no. 3, pp. 1037-1040, 1982.

[18] W. J. Geary, "The use of conductivity measurements in organic solvents for the characterisation of coordination compounds," Coordination Chemistry Reviews, vol. 7, no. 1, pp. 81-122, 1971.

[19] E. Fredericq, A. Oth, and F. Fontaine, "The ultraviolet spectrum of deoxyribonucleic acids and their constituents," Journal of Molecular Biology, vol. 3, no. 1, pp. 11-17, 1961.

[20] E. Gratton, N. Silva, G. Mei, N. Rosato, I. Savini, and A. Finazzi-Agro, "Fluorescence lifetime distribution of folded and unfolded proteins," International Journal of Quantum Chemistry, vol. 42, no. 5, pp. 1479-1489, 1992.

[21] J. A. Robson, F. Gonzàlez De Rivera, K. A. Jantan et al., "Bifunctional chalcogen linkers for the stepwise generation of multimetallic assemblies and functionalized nanoparticles," Inorganic Chemistry, vol. 55, no. 24, pp. 12982-12996, 2016.

[22] M. C. Barral, R. Jiménez-Aparicio, E. C. Royer et al., "Synthesis and crystal structure of a ruthenium complex containing two monodentate DPPM ligands (DPPM = bis(diphenylphosphino)methane)," Inorganica Chimica Acta, vol. 209, no. 1, pp. 105-109, 1993.

[23] K. Nakamoto, Infrared and Raman Spectra of Inorganic and Coordination Compounds, Wiley-Interscience, New York, NY, USA, 5th edition, 1997.

[24] W. Lewandowski, M. Kalinowska, and H. Lewandowska, “The influence of metals on the electronic system of biologically important ligands. Spectroscopic study of benzoates, salicylates, nicotinates and isoorotates. Review," Journal of Inorganic Biochemistry, vol. 99, no. 7, pp. 1407-1423, 2005.

[25] P. Lincoln, E. Tuite, and B. Norden, "Short-circuiting the molecular wire: cooperative binding of $\Delta$-[Ru(phen)2dppz $] 2+$ and $\Delta$-[Rh(phi)2bipy]3+ to DNA," Journal of the American Chemical Society, vol. 119, no. 6, pp. 1454-1455, 1997.

[26] V. I. Ivanov, L. E. Minchenkova, A. K. Schyolkina, and A. I. Poletayev, "Different conformations of double-stranded nucleic acid in solution as revealed by circular dichroism," Biopolymers, vol. 12, no. 1, pp. 89-110, 1973.

[27] B. Norden and F. Tjerneld, "Structure of methylene blue-DNA complexes studied by linear and circular dichroism spectroscopy," Biopolymers, vol. 21, no. 9, pp. 1713-1734, 1982.

[28] P. Uma Maheswari and M. Palaniandavar, "DNA binding and cleavage properties of certain tetrammine ruthenium(II) complexes of modified 1,10-phenanthrolines - Effect of hydrogenbonding on DNA-binding affinity," Journal of Inorganic Biochemistry, vol. 98, no. 2, pp. 219-230, 2004.

[29] F. Dimiza, A. N. Papadopoulos, V. Tangoulis et al., "Biological evaluation of cobalt(II) complexes with non-steroidal antiinflammatory drug naproxen," Journal of Inorganic Biochemistry, vol. 107, no. 1, pp. 54-64, 2012.

[30] L. Shang, Y. Wang, J. Jiang, and S. Dong, "PH-dependent protein conformational changes in albumin:Gold nanoparticle bioconjugates: a spectroscopic study," Langmuir, vol. 23, no. 5, pp. 2714-2721, 2007.

[31] M. Ganeshpandian, R. Loganathan, E. Suresh, A. Riyasdeen, M. A. Akbarsha, and M. Palaniandavar, "New ruthenium(II) arene complexes of anthracenyl-appended diazacycloalkanes: effect of ligand intercalation and hydrophobicity on DNA and protein binding and cleavage and cytotoxicity," Dalton Transactions, vol. 43, no. 3, pp. 1203-1219, 2014.

[32] X. Zhao, R. Liu, Z. Chi, Y. Teng, and P. Qin, "New insights into the behavior of bovine serum albumin adsorbed onto carbon 
nanotubes: comprehensive spectroscopic studies," Journal of Physical Chemistry B, vol. 114, no. 16, pp. 5625-5631, 2010.

[33] R. S. Correa, K. M. Oliveira, H. Pérez et al., "cis-bis(N-benzoylN',N'-dibenzylthioureido)platinum(II): Synthesis, molecular structure and its interaction with human and bovine serum albumin," Arabian Journal of Chemistry, vol. 2015, 2015.

[34] R. S. Correa, K. M. De Oliveira, F. G. Delolo et al., "Ru(II)based complexes with $\mathrm{N}$-(acyl)-N/,N/-(disubstituted)thiourea ligands: synthesis, characterization, BSA- and DNA-binding studies of new cytotoxic agents against lung and prostate tumour cells," Journal of Inorganic Biochemistry, vol. 150, article 9708, pp. 63-71, 2015.

[35] L. Colina-Vegas, J. L. Dutra, W. Villarreal et al., "Ru(II)/clotrimazole/diphenylphosphine/bipyridine complexes: Interaction with DNA, BSA and biological potential against tumor cell lines and Mycobacterium tuberculosis," Journal of Inorganic Biochemistry, vol. 162, pp. 135-145, 2016.

[36] M. Mathew, S. Sreedhanya, P. Manoj, C. T. Aravindakumar, and U. K. Aravind, "Exploring the interaction of bisphenol-S with serum albumins: a better or worse alternative for bisphenol A?" Journal of Physical Chemistry B, vol. 118, no. 14, pp. 3832-3843, 2014.

[37] B. Ojha and G. Das, "The interaction of 5-(Alkoxy)naphthalen1-amine with bovine serum albumin and Its effect on the conformation of protein," Journal of Physical Chemistry B, vol. 114, no. 11, pp. 3979-3986, 2010.

[38] S.-L. Zhang, G. L. V. Damu, L. Zhang, R.-X. Geng, and C.-H. Zhou, "Synthesis and biological evaluation of novel benzimidazole derivatives and their binding behavior with bovine serum albumin," European Journal of Medicinal Chemistry, vol. 55, pp. 164-175, 2012.

[39] P. D. Ross and S. Subramanian, "Thermodynamics of protein association reactions: forces contributing to stability," Biochemistry, vol. 20, no. 11, pp. 3096-3102, 1981. 

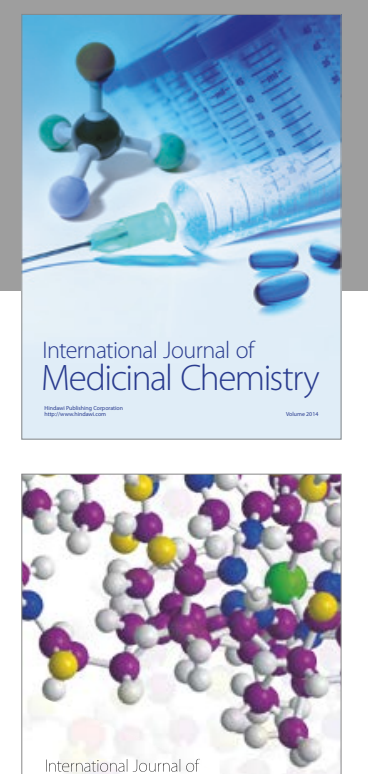

Carbohydrate Chemistry

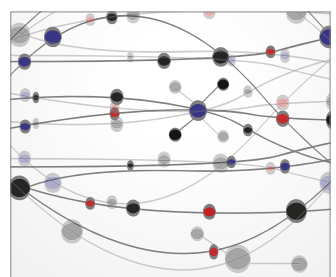

The Scientific World Journal
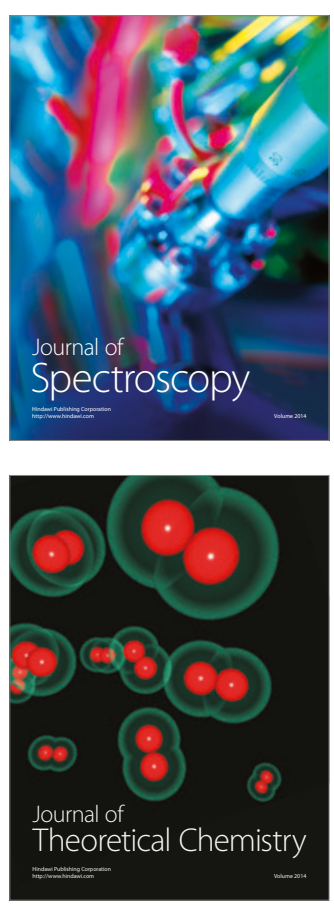
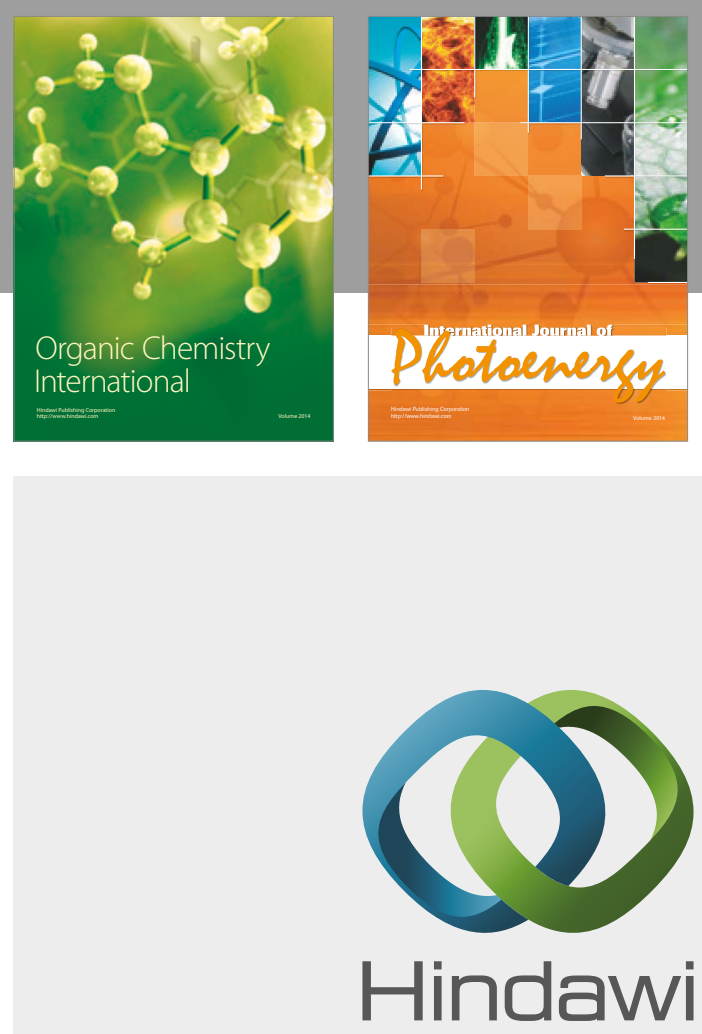

Submit your manuscripts at

https://www.hindawi.com

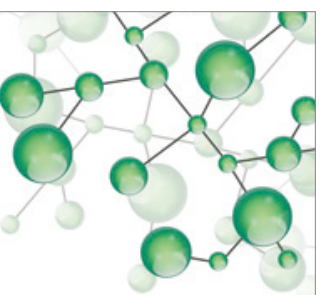

International Journal of

Inorganic Chemistry

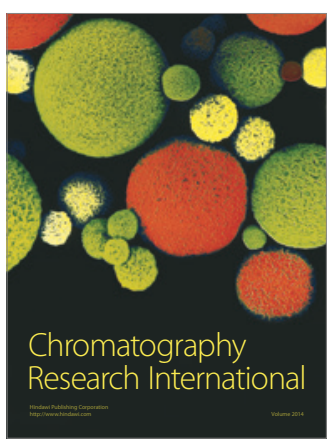

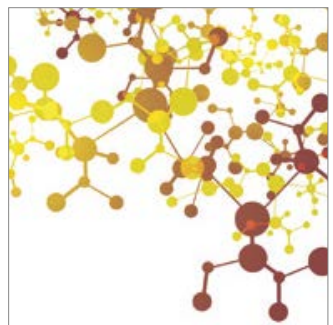

Applied Chemistry
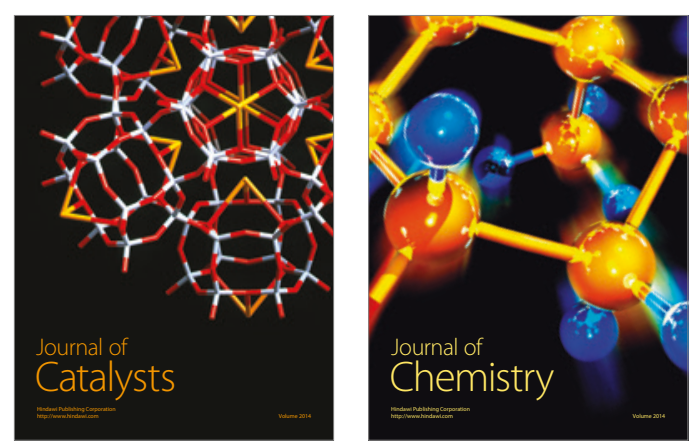
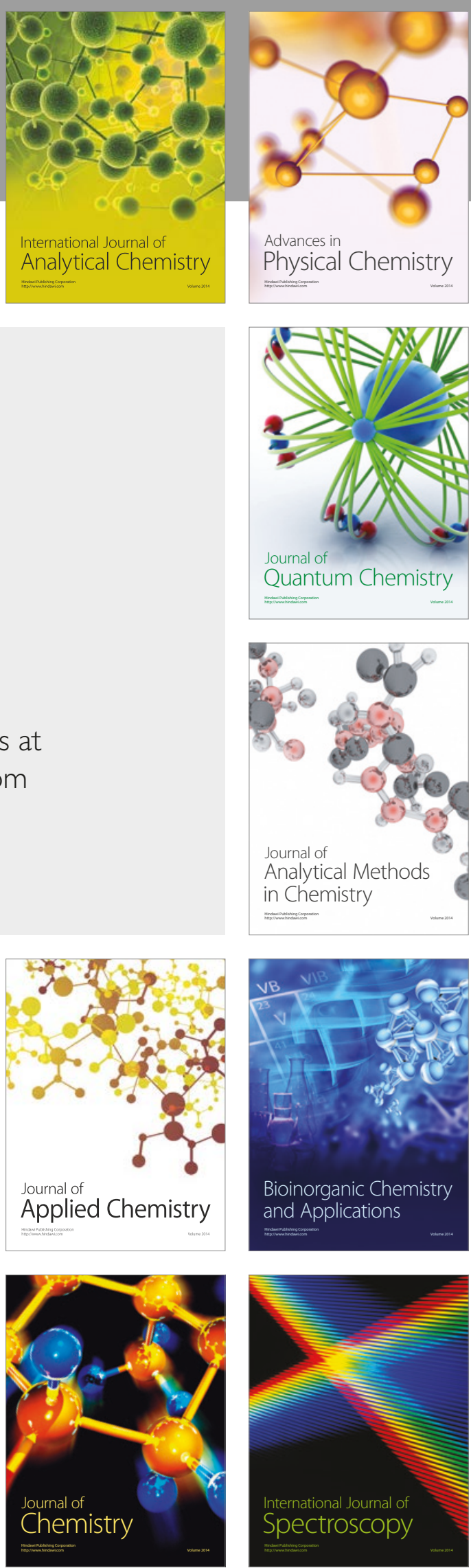